\title{
EVENTOS ÍGNEOS DA SUÍTE METAMÓRFICA PORONGOS NA ÁREA DA ANTIFORME CAPANÉ, CACHOEIRA DO SUL - RS.
}

\author{
JULIANA CHARÃO MARQUES*, HARDY JOST*,ARI ROISENBERG** \& JOSÉ CARLOS FRANTZ**
}

\begin{abstract}
IGNEOUS EVENTS OF THE PORONGOS METAMORPHIC SUITE IN THE CAPANE ANTIFORM AREA, CACHOEIRA DO SUL, SOUTEHRN BRAZIL The Neoproterozoic Porongos Metamorphic Suite, Southern Brazil, has a large lithologic variety of igneous protoliths in the Capane Antiform area. These include felsic, intermediate and mafic metavolcanic rocks, metagranitoids and alkaline gneisses. Major and minor oxides and trace elements, including REE, indicate that the felsic metavolcanics are similar to calcalkaline suites, while intermediate and mafic metavolcanic rocks are transitional to tholeiitic. The high REE and LILE contents, and the field relations suggest that the volcanism can be explained by means of subduction of an oceanic crust under a pre-existing continent, probably represented by the Paleoproterozoic Encantadas Gneisses. The field relations and chemical composition of the metagranitoids are compatible with a calcalkaline intrusion sin-kinematic in relation to the main deformation event of Porongos Metamorphic Suite. The alkaline gneisses are pre-kinematic and could represent a rift event that took place before or simultaneously with the basin stage of the Porongos Suite. The intercalation of metachert in metavolcanic rocks and the relicts of tuff textures of felsic metavolcanics indicate that at least part of the volcanism occurred as sub-aqueous eruptions, in part explosive.

Keywords: litochemistry, metavolcanics, metagranitoids, alkaline gneisses, Capané Antiform, Porongos Metamorphic Suite

RESUMO Na área da Antiforme Capané, a Suite Metamórfica Porongos, do Neoproterozóico, possui uma grande variedade litológica de protólitos ígneos. Estes incluem metavulcânicas félsicas, intermediárias e maricas, metagranitóides e gnaisses alcalinos. Dados de óxidos de elementos maiores e menores e de elementos traço, incluindo ETR, das rochas metavulcânicas félsicas são compatíveis com suites cálcio-alcalinas e das metavulcânicas intermediárias e máficas com suites transicionais a toleíticas. O conteúdo elevado de ETR e LILE e as relações de campo sugerem vulcanismo associado à subducção de crosta oceânica sob um continente preexistente, provavelmente representado pêlos Gnaisses Encantadas, do Paleoproterozóico. As relações de campo e os dados químicos indicam que o metagranitóide é uma intrusão de filiação cálcio-alcalinas, sin-cinemática à deformação principal da Suite Metamórfica Porongos. Os gnaisses alcalinos são pré-cinemáticos e podem representar um magmatismo associado a um evento extensional anterior ou concomitante à fase de bacia da Suite Porongos. A presença de metachert nas rochas metavulcânicas e as relíquias de textura de tufos das metavulcânicas félsicas indicam que o vulcanismo foi, em parte, sub-aquoso e explosivo.
\end{abstract}

Palavras-chave: litoquímica, metavulcânicas, metagranitóides, gnaisses alcalinos, Antiforme Capané, Suite Metamórfica Porongos

INTRODUÇÃO A Suite Metamórfica Porongos (Jost \& Bitencourt 1980) é uma associação de rochas supracrustais que ocorrem no interior de uma faixa de orientação NE, com cerca de $150 \mathrm{~km}$ de comprimento e largura inferior a $50 \mathrm{~km}$. A Suite é melhor conhecida na sua porção localizada a norte do Rio Camaquã, onde sustenta três megaestruturas orientadas segundo NE-SW e denominadas por Jost \& Bitencourt (1980) de Domo de Santana da Boa Vista, Antiforme Serra dos Pedrosas e Antiforme Capané (Fig. 1). A sul do Rio Camaquã, a Suite também está estruturada em megaestruturas antiformais, dentre as quais a do Godinho, localizada na região do Passo da Cuia, formada por rochas semelhantes às descritas ao norte (Wildner et al. 1996).

O Domo de Santana é uma estrutura alongada cujo núcleo expõe uma infra-estrutura composta por rochas do embasamento (Gnaisse Encantadas e Granitóides Milonitizados de Santana da Boa Vista) e uma supra-estrutura composta por metapelitos, quartzitos e mármores da Suite Metamórfica Porongos. A Antiforme Serra dos Pedrosas, situada a leste do Domo, consiste principalmente de rochas metavulcânicas intermediárias a ácidas, subordinadamente metapelitos e xistos grafitosos (Jost 1981, Jost e Bitencourt 1980, Marques \& Caravaca 1994). A Antiforme Capané, localizada no extremo norte da faixa, foi alvo de um mapeamento em escala 1:50.000 realizado durante o trabalho de graduação de formandos do Curso de Geologia da UNISINOS em 1978, ao qual se seguiram estudos sobre temas específicos (Jost e Hartmann 1979, Hartmann \& Jost 1980), e de formandos do curso de geologia da UFRGS em 1994

Dados geocronológicos da Suite Metamórfica Porongos são ainda escassos. Teixeira (1982) obteve uma idade $\mathrm{Rb} / \mathrm{Sr}$ convencional de 915 Ma em milonito gnaisse da região de Santana da Boa Vista. Soliani Jr. (1986) datou, pelo mesmo método, rochas metavulcânicas intermediárias da Formação Cerro Cambará do Complexo Cerro da Árvore, obtendo uma idade de $\pm 800 \mathrm{Ma}$, interpretada como a idade máxima do vulcanismo. Mais recentemente, Wildner et al. (1996) dataram rochas metandesitos da Antiforme do Godinho pelo método $\mathrm{U} / \mathrm{Pb}$ em zircão e obtiveram uma idade de $1.356 \pm 227 \mathrm{Ma}$, a qual, apesar do amplo intervalo, corresponderia à idade do vulcanismo da Suite Metamórfica Porongos.

Este artigo visa descrever e interpretar dados de campo, petrográficos e petroquímicos das diferentes unidades vulcânicas e intrusivas da Suite Metamórfica Porongos que afloram no domínio da Antiforme Capané.

GEOLOGIA DA ANTIFORME CAPANÉ A Suite Metamórfica Porongos na Antiforme Capané apresenta intensa deformação regis- trada em duas foliações $\left(\mathrm{S}_{1}\right.$ e $\left.\mathrm{S}_{2}\right)$ paralelas e originalmente de baixo ângulo de mergulho que formam uma foliação composta, por fim orientada segundo um padrão antiformal. $\mathrm{O}$ metamorfismo atingiu a fácies anfibolito inferior durante $\mathrm{S}_{1}$, seguido da fácies xisto verde em $\mathrm{S}_{2}$ (Marques et al. 1998).

A deformação foi heterogênea, permitindo a preservação local de texturas e mineralogia originais, o que possibilitou a subdivisão da Suite, na área, em uma sequência com predomínio de rochas de origem sedimentar e uma dominantemente vulcânica (Fig. 2). A sequência metassedimentar ocorre preferencialmente na porção central e no flanco leste da estrutura e é constituída de metapelitos, quartzitos, mais raramente metaconglomerados e mármores (Marques et al. 1998). A sequência metavulcẩnica compreende dois conjuntos principais, um de caráter máfico a intermediário e outro félsico. Ambas sequências estão orientadas preferencialmente segundo NE-SW e são intrudidas por um metagranitóide leucocrático que forma lentes decamétricas também segundo direção NE-SW. Sheets de gnaisses alcalinos e rochas metaultramáficas ocorrem imbricadas na sequência, segundo a mesma direção. As rochas metaultramáficas consistem de pequenos corpos de serpentinitos, por vezes com lentes de cromitito (Jost \& Hartmann 1979, Marques 1996).

DESCRIÇÃO PETROGRÁFICA O estudo petrográfico das ro chas metavulcânicas, do metagranitóide e dos gnaisses alcalinos da antiforme objetivaram identificar e caracterizar as unidades litológicas originais. Por esta razão, a descrição a seguir enfatiza, sempre que possível, feições primárias observadas em amostras colhidas em locais com pouca intensidade de deformação.

Rochas metavulcânicas As rochas metavulcânicas compreendem dois grupos litológicos principais. Um compreende rochas máficas a intermediárias, as quais afloram apenas no flanco oeste da antiforme. Outro é composto de metavulcânicas félsicas, mais frequentes e em geral representadas por metatufos, ora intercalados em rochas metassedimentares, ora associados às metavulcânicas máficas a intermediárias. Os pacotes tufáceos podem, localmente, conter expressiva contribuição sedimentar. Bancos de metachert ocorrem como intercalações em ambos grupos.

METAVULCÂNICAS MÁFICAS A INTERMEDIÁRIAS As rochas metavulcânicas máficas a intermediárias são cinza a verde escuras e ocorrem em camadas de espessura centimétrica a métrica. O acamamento original se manifesta pela alternância de níveis que diferem na granulação, nas proporções dos minerais essenciais, na presença ou

* Instituto de Geociências, Universidade de Brasilia, Campus Asa Norte, CEP 70910-900, Brasília, DF, e-mail: jcmarq@guarany.cpd.unb.br, hjost@tba.com.br

** Instituto de Geociências, Universidade Federal do Rio Grande do Sul, Campus do Vale, Av. Bento Gonçalves 9500, CEP 91540-000, Porto Alegre, e-mail:ariberg@iffufrgs.br 


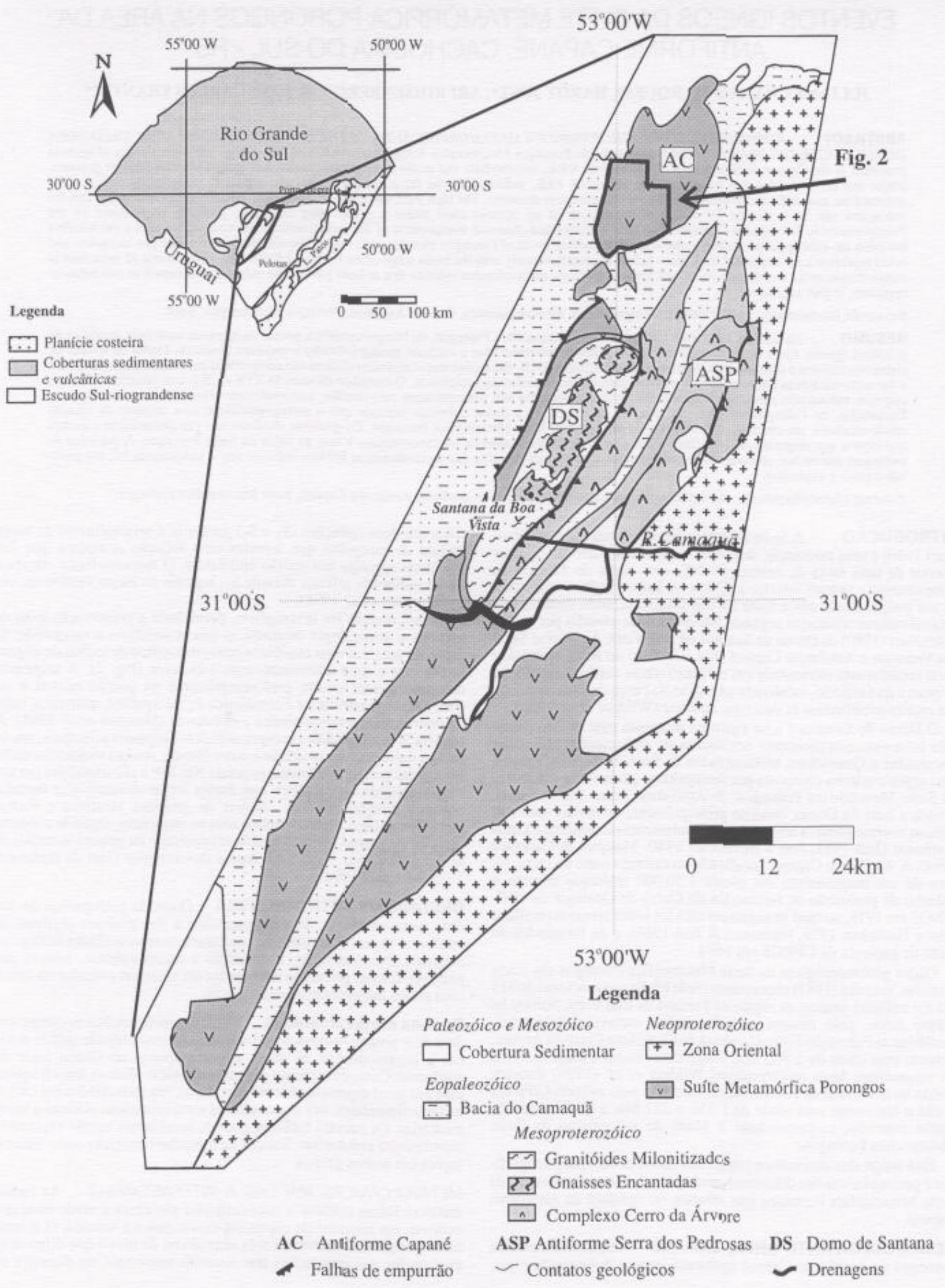

Figura l- Mapa geológico simplificado da parte central do escudo Sul-rio-grandense, mostrando a área de ocorrência da Suite Metamórfica Porongos (extraido de Santos et al. J989). 
ausência de relíquias de textura fanerítica ou porfirítica e, ainda, pela intercalação de bancos centimétricos de metachert bandado, por vezes ricos em pirita.

Estas rochas metavulcânicas comumente apresentam de 20 a 30\% de fenoclastos de plagioclásio com 0,3 a 3,0 mm de diâmetro, disseminados em uma matriz muito fina com textura nematoblástica a lepidoblástica e granoblástica, dependendo da composição e da intensidade de deformação (Fig. 3a,b). A mineralogia das rochas máficas consiste de plagioclásio (25-30\%), anfibólio (30-35\%), Mg-clorita $(15-20 \%)$, biotita $(10-15 \%)$, quartzo (3-5\%), pirita (3-5\%) e apatita (1-3\%). Em menor proporção ocorrem clinopiroxênio, epidoto, titanita, mica branca e carbonato. A mineralogia das rochas intermediárias é semelhante, porém estas rochas apresentam maiores proporções de plagioclásio (30-35\%) e quartzo (5-10\%), menores de apatita e ausência de clinopiroxênio.

$\mathrm{O}$ plagioclásio $\left(\mathrm{An}_{15-25}\right)$ ocorre principalmente como fenoclastos com 0,5-2,5 mm de diâmetro (Fig. 3c), mas também como constituinte da matriz. Os grãos são angulosos, localmente ripiformes. O anfibólio, possivelmente $\mathrm{Fe}$-actinolita a Fe-tschermakita dependendo da fácies, ocorre como fenoclastos $(0,3-1,0 \mathrm{~mm})$ ripiformes com núcleos de clinopiroxênio (Fig. 3d) e como constituinte da matriz, onde está parcialmente substituído por clorita e biotita. O quartzo, mais abun- dante nas rochas intermediárias, é parte da matriz, onde está recristalizado. Nas rochas máficas, a pirita ocorre como fenoblastos subédricos a euédricos, de até $7,5 \mathrm{~mm}$ de comprimento, e nas intermediárias é um constituinte da matriz. A apatita é ripiforme e está inclusa em plagioclásio, mas pode, localmente, ocorrer como fenoclasto de ate $0,3 \mathrm{~mm}$ de diâmetro. $\mathrm{O}$ epidoto forma cristais subédricos $(0,1$ e $0,3 \mathrm{~mm})$ e está disseminado na matriz. A titanita é rara, euédrica e de diâmetro inferior a $0,5 \mathrm{~mm}$. A mica branca ocorre como alteração do plagioclásio. $\mathrm{O}$ carbonato é raro e forma diminutos cristais ou agregados na matriz.

METAVULCÂNICAS FÉLSICAS As rochas metavulcânicas félsicas apresentam características mesoscópicas variadas, com predomínio de termos finos, silicificados e de cor cinza. Em alguns afloramentos, estas rochas contêm fenoclastos de feldspato e quartzo, cujas proporções variam entre 25 e $35 \%$ nos termos menos deformados até menos de $10 \%$ nos mais deformados. Bandas milimétricas a centimétricas ricas em quartzo, descontínuas, dobradas ou em boudins são frequentes. Lentes de metachert com sulfetos ocorrem como intercalações locais nas metavulcânicas félsicas.

Em exemplares menos deformados e mais grossos, os fenoclastos possuem diâmetro médio de $0,5 \mathrm{~mm}$, mas podem alcançar até $2,0 \mathrm{~mm}$ (Fig. 4a). Nos mais finos, os fenoclastos possuem diâmetro inferior a

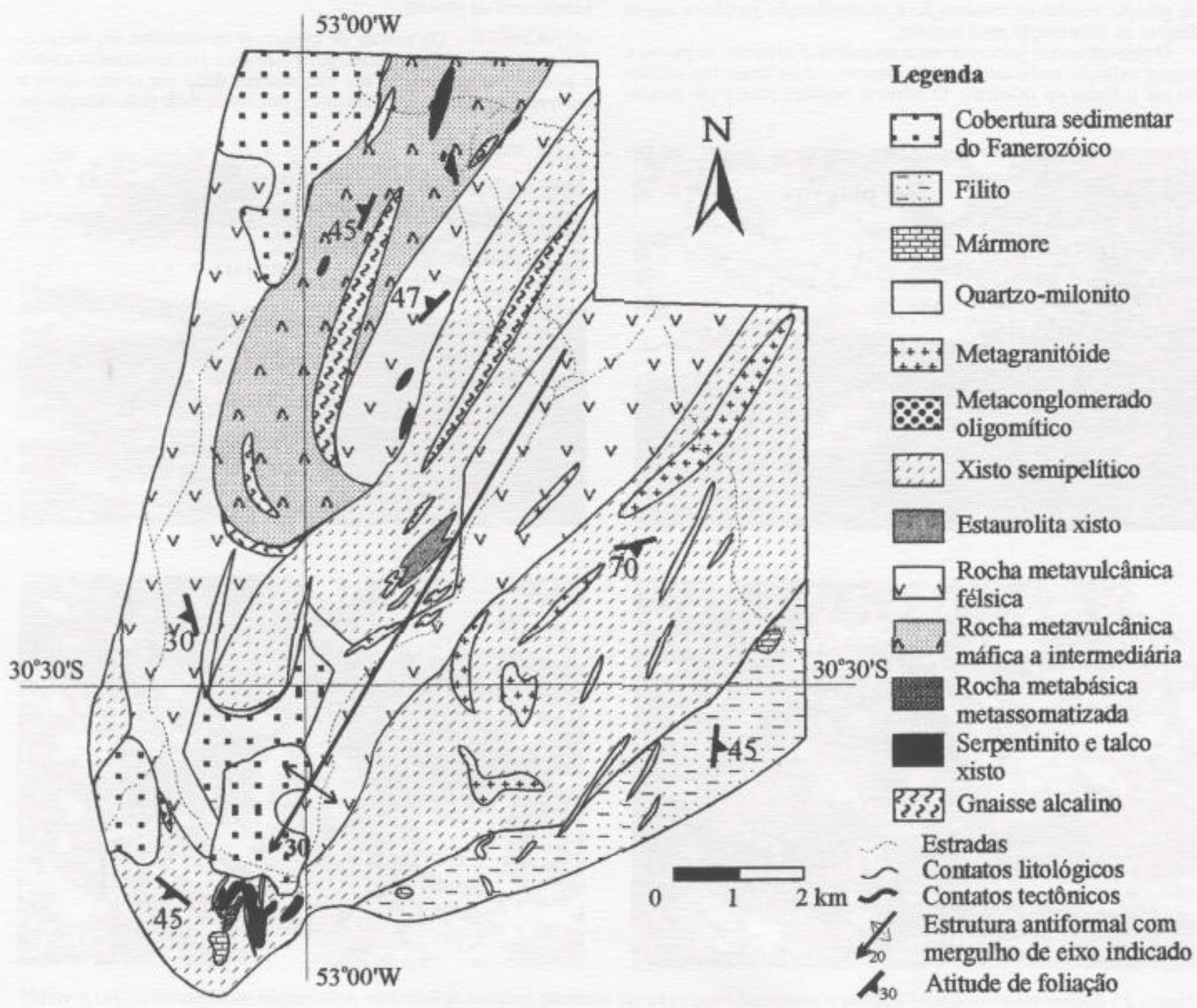

Figura 2 - Mapa geológico simplificado da área estudada (Suite Metamórfica Porongos - Antiforme Capané). 
$0,4 \mathrm{~mm}$. A matriz dessas rochas tem textura granoblástica fina a muito fina e a maioria dos cristais são angulosos, sugerindo relíquias de tufos de cristal e de cinza recristalizada. Amostras mais deformadas possuem fenoclastos imersos em uma matriz com textura lepidoblástica composta por mica branca com estrutura do tipo micafish (Fig. 4b). Em amostras muito deformadas, a ausência de texturas primárias e a redução de tamanhos de grão comumente dificulta a distinção entre amostras de metavulcânicas félsicas, metapelitos e metagranitóides intensamente deformados por cisalhamento.

Estas rochas são compostas de feldspato potássico (25-35\%), quartzo (25-35\%), plagioclásio (5-15\%) e minerais micáceos (25$35 \%$ ) representados por proporções variadas de mica branca, biotita e clorita. Os acessórios compreendem magnetita, pirita, apatita, zircão, turmalina, epidoto e, por vezes, também, granada.

$\mathrm{O}$ feldspato potássico ocorre como fenoclastos angulosos e como constituinte da matriz. Os cristais podem apresentar macias, extinção ondulante, fraturas, e nas porções mais deformadas, apresentam seções elípticas, bordos e caudas granulados e recristalizados. Inclusões de minerais opacos e apatita, e alteracão para mica branca são comuns. Quando constituinte da matriz, o feldspato é anédrico, tem contatos suturados, apresenta formação de subgrãos e fitas.

O plagioclásio ocorre principalmente na matriz, mais raramente como fenoclastos de diâmetro inferior a $0,5 \mathrm{~mm}$ com núcleo, em geral, alterado para mica branca. Quando zonados, o núcleo tem a composição de $\left.\mathrm{An}_{102} \mathrm{O}\right)$ e as bordas são mais sódicas $\left(\mathrm{An}_{5-10}\right)$. Os fenoclastos têm seção angulosa, prismática ou elíptica. Macias em chama, sombras de pressão, caudas de cominuição e recristalização periférica são as feições de deformação mais comuns.

O quartzo ocorre principalmente na matriz, é anédrico, anguloso e possui extinção ondulante, mas localmente ocorre como fenoclastos de até $0,5 \mathrm{~mm}$ de diâmetro. $\mathrm{O}$ mineral também ocorre em bandas
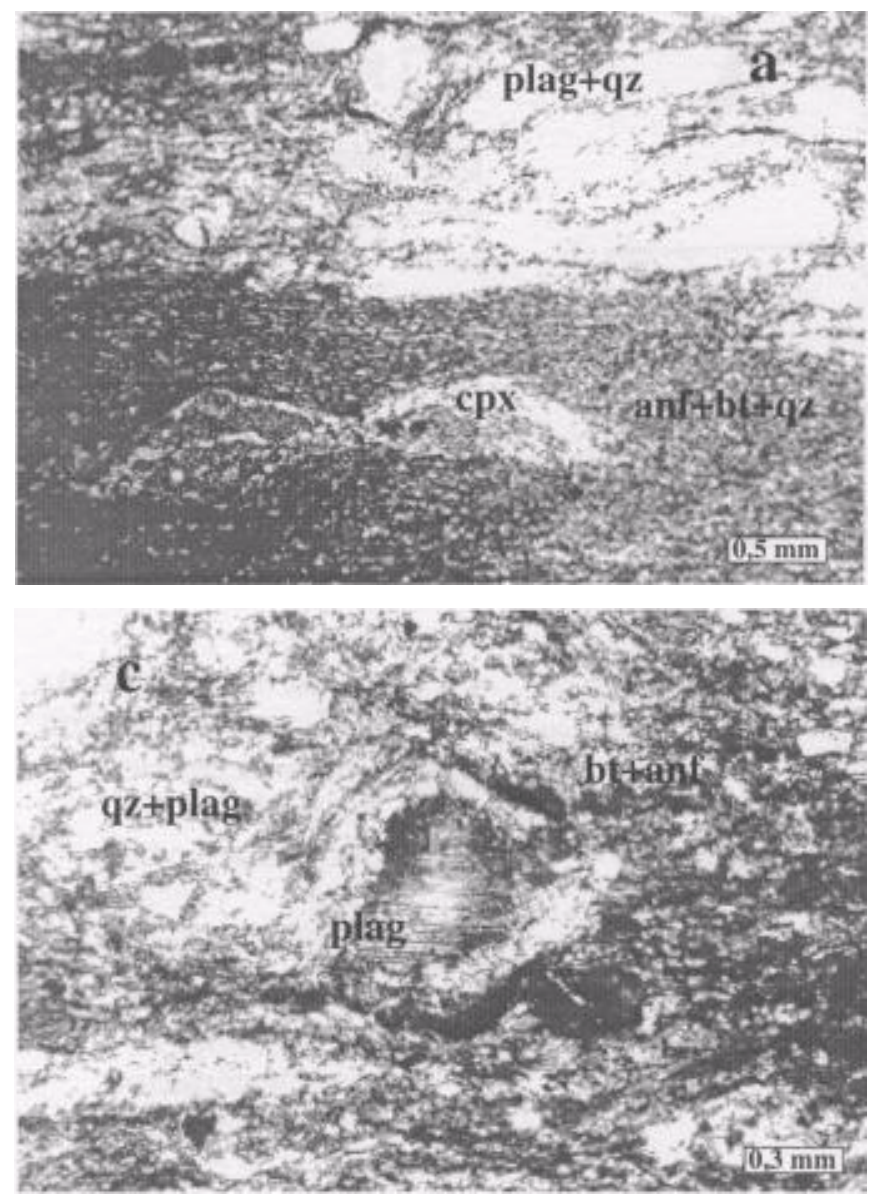

paralelas à foliação, as quais consistem de agregados de subgrãos recristalizados.

A mica branca ocorre como alteração de feldspatos, como constituinte da matriz ou, ainda, como fenoblastos. A variedade inclusa em feldspatos é muito fina, desenvolveu-se com orientação aleatória e, quando em plagioclásio, está preferencialmente concentrada no núcleo mais cálcico. A variedade da matriz tem aspecto sujo, é fina, define a foliação metamórfica e tende a se concentrar em trilhas. Os fenoclastos podem ter até $3 \mathrm{~mm}$ de diâmetro e ora ocorrem como micafish e ora circundam fenoclastos de feldspato e, em contraste com as demais variedades, possuem inclusões de magnetita ou de pirita.

A biotita e clorita são muito finas, ocorrem intimamente intercrescidas e suas proporções são variáveis. A biotita é restrita à matriz e a clorita, além de constituir parte da matriz, pode também formar películas em torno de fenoclastos de feldspato. A granada é rara e ocorre como porfiroblastos euédricos rotacionados de até $4,0 \mathrm{~mm}$ de diâmetro, os quais são acompanhados de sombras de pressão contendo feldspato potássico, opacos, clorita e mica branca. Magnetita e pirita ocorrem como inclusões euédricas com diâmetro inferior a $0,1 \mathrm{~mm}$ ao longo da clivagem de porfiroblastos de mica branca, no interior da granada delineando uma foliação $S$, ou como constituintes da matriz. A apatita ocorre como inclusões aciculares nos feldspatos. O zircão é subédrico. fraturado e está, normalmente incluso em biotita. A turmalina e o epidoto ocorrem como cristais euédricos a subédricos, fraturados. orientados ou não segundo a foliação, e sua abundância cresce com a proximidade de metagranitóides, sugerindo uma possível origem hidrotermal de contato.

METACHERT Os bancos de metachert intercalados em metavulcânicas possuem espessura em geral inferior a $1 \mathrm{~m}$, são brancos a cinza e geralmente apresentam um bandamento dado por níveis claros e escuros alternados. O bandamento é, por vezes, dado pela variação das
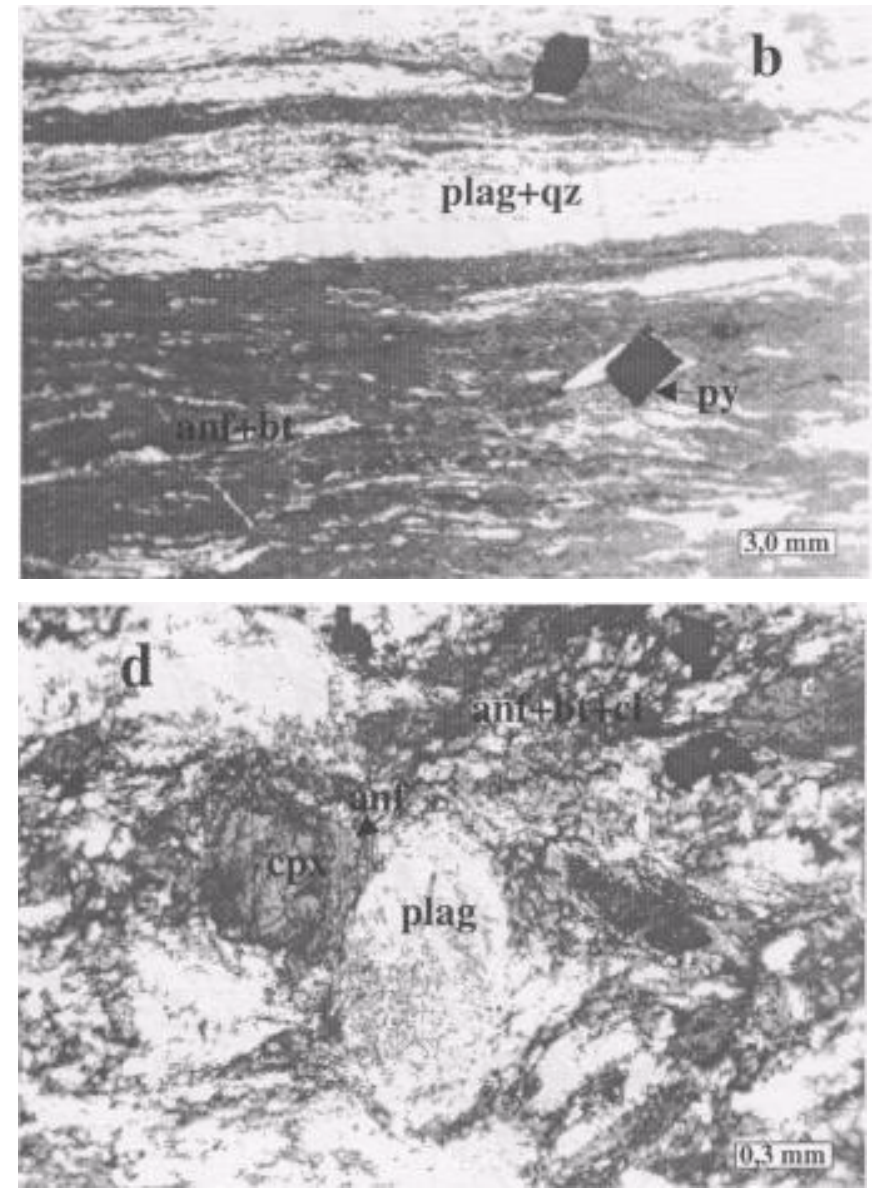

Figura 3 - Rochas metavulcânicas máficas a intermediárias, (a) e (b) mostram texturas típicas com deformação aumentando de (a) para (b). Notar em (b) pirita tardi a pós-cinemático. (c) fenodasto de plagioclásio recristalizado nas bordas, (d) fenodasto de plagioclásio em contato com fenodasto de clinopiroxênio parcialmente transformado em anfibólio. anf - anfibólio, bt - biotita, cl - clorita, cpx - clinopiroxênio, plag plagioclásio, py -pirita, qz - quartzo. 
proporções de pirita. Estas rochas têm textura granoblástica fina, e de forma subordinada, lepidoblástica e são constituídas por quartzo (60$70 \%$ ), pirita $(5-7 \%)$ e clorita \pm biotita $(25-30 \%)$.

Em amostras menos deformadas, o quartzo tem diâmetro médio de $1,5 \mathrm{~mm}$, está recristalizado e apresenta fraca extinção ondulante, a pirita ocorre como cristais euédricos disseminados e a biotita ocorre em lamelas sem orientação preferencial que atingem até $0,1 \mathrm{~mm}$ de comprimento. Com aumento da deformação, o quartzo apresenta granulação inferior a $0,5 \mathrm{~mm}$, a pirita forma finas bandas de agregados concordantes com a foliação e a biotita está parcialmente transformada em clorita.

Metagranitóides Os metagranitóides ocorrem como lentes paralelas à foliação das supracrustais, em ambos flancos da antiforme, mas são mais abundantes próximo à zona de charneira. A proximidade destas lentes é, em geral, detectada pela abundância de veios de quartzo leitoso e apófises milimétrica a centimétricas em meio às supracrustais. Estas injeções secundárias são preferencialmente paralelas à foliação, resultando em xistos bandados. As bandas quartzo-feldspáticas estão, em geral, dobradas de forma apertada em conjunto com os xistos ou formam boudins. Estas características estruturais e a ausência de metamorfismo de contato sugerem que as injeções foram sin-cinemáticas.

Os metagranitóides são rosa claro, finos a médios e apresentam uma pronunciada foliação, localmente também um bandamento composicional dado pela alternância de níveis ora mais ricos em quartzo e feldspato ora em biotita. A composição quartzo-feldspática, a pronunciada foliação, a presença de fitas de quartzo e feldspato, de fenoclastos rotacionados com caudas de destruição, sombras de pressão e uma forte lineação de estiramento caracterizam os afloramentos dos metagranitóides. Dobras apertadas, boudins e rods com até vários metros de extensão também são comuns.
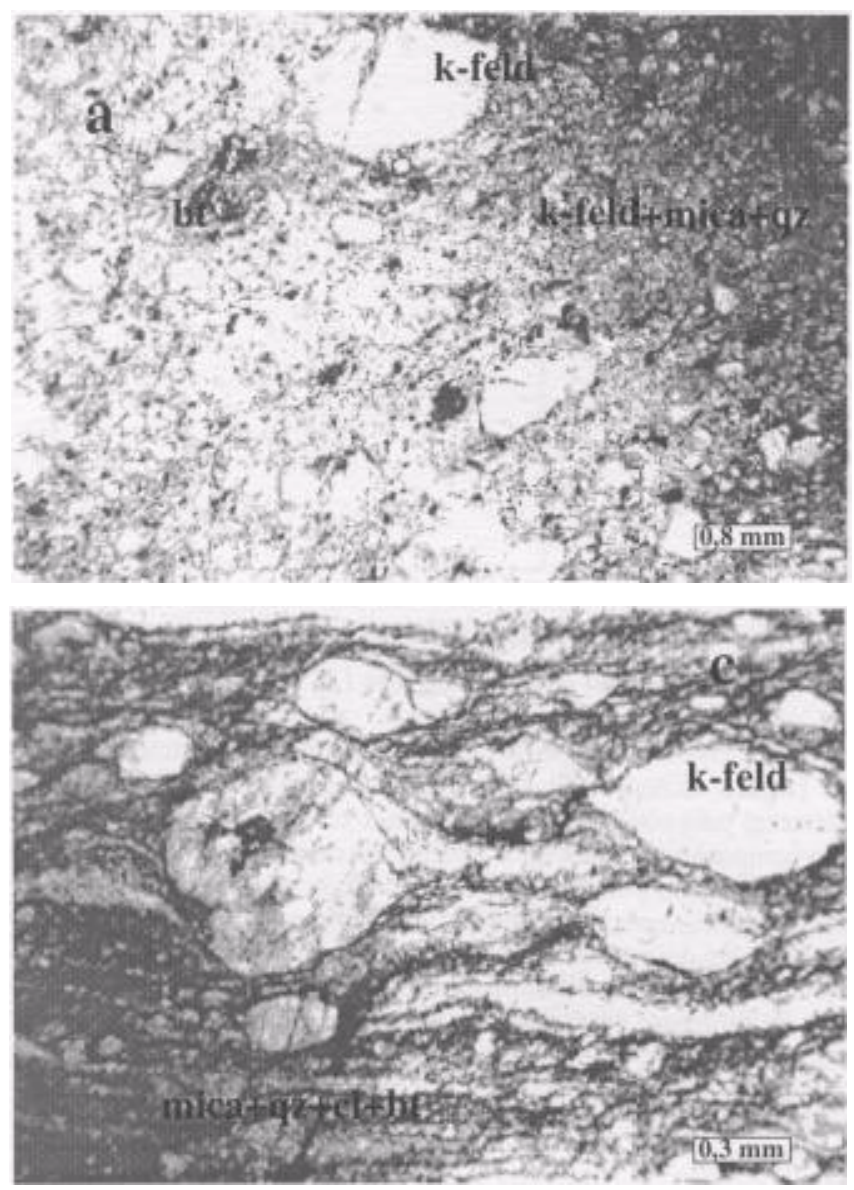

As amostras de metagranitóide apresentam uma textura porfiroclástica proeminente. Os fenoclastos são elipsoidais e de diâmetro que varia desde $5 \mathrm{~mm}$ até $0,4 \mathrm{~mm}$ (Fig. 4c), de acordo com a intensidade crescente de deformação. Nas porções menos deformadas, os porfiroclastos perfazem entre 50 e $60 \%$ da rocha. A matriz exibe textura milonítica de granulação decrescente com a intensa de deformação, o que é acompanhado pelo aumento na quantidade de micas e óxidos de ferro, fitas de quartzo e caudas de destruicão de feldspato, marcadores da foliação e das lineações. Os exemplares estudados apresentam textura que varia de protomilonítica a ultramilonítica. A matriz resultante de cominuição de grãos está inteiramente recristalizada sob condições da fácies xisto verde, compatível com o retrometamorfismo das rochas encaixantes durante a formação de $\mathrm{S}_{2}$ nestas.

As amostras menos deformadas de metagranitóides consistem de feldspato potássico $(55-60 \%)$, quartzo $(25-30 \%)$ e plagioclásio (10$15 \%$ ). Com aumento da deformação, o feldspato potássico e o plagioclásio dão lugar a proporções crescentes de mica branca, a qual pode, então, alcançar até $25 \%$ da rocha, originando xistos feldspáticos. Biotita, apatita, opacos, epidoto, clorita e carbonato ocorrem como traços.

O feldspato potássico ocorre como fenoclastos e na matriz. Os fenoclastos variam de 3,0 a 5,0 mm de diâmetro. Os grãos diminuem com o aumento da deformação devido à cominuição periférica, adquirem seção oval e longas caudas de destruição, muitas das quais assimétricas. Outras feiçỗes de deformação incluem fraturas, exsolucão de albita e quartzo, macias em chama e kink-bands. Na matriz, o feldspato varia de 0,2 a $0,1 \mathrm{~mm}$ de diâmetro e nos termos mais preservados, apresenta textura equigranular com junções tríplices. Com o avanco da deformação, os contatos passam a suturados, o grãos estão recristalizados e com forte extinção ondulante e, em casos extremos, constituem longas fitas.

O quartzo da matriz tem diâmetro entre 0,2 e $0,05 \mathrm{~mm}$, ou está concentrado em ribbons monominerálicas ou com feldspato, sempre
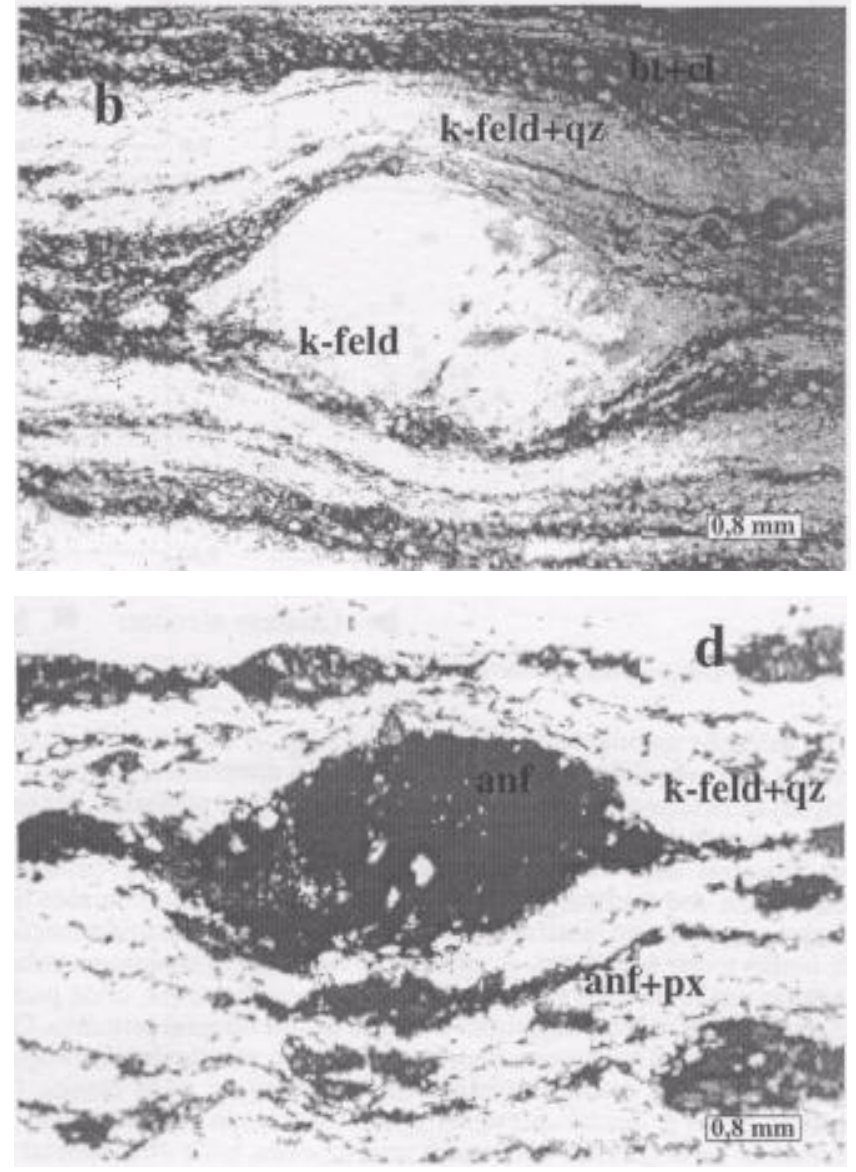

Figura 4-(a) e (b) rochas metavulcânicas félsicas com deformação crescente de (a) para (b), (c) metagranitóide comfenoclastos arredondados de K-feldspato. (d) gnaisse alcalino com fenodasto de riebeckita. anf - anflbólio, bt - biotita, cl - clorita, K-feld - K-feldspato, mica - mica branca, $\boldsymbol{p x}$ - piroxênio, $\mathbf{q z}$ - quartzo. 

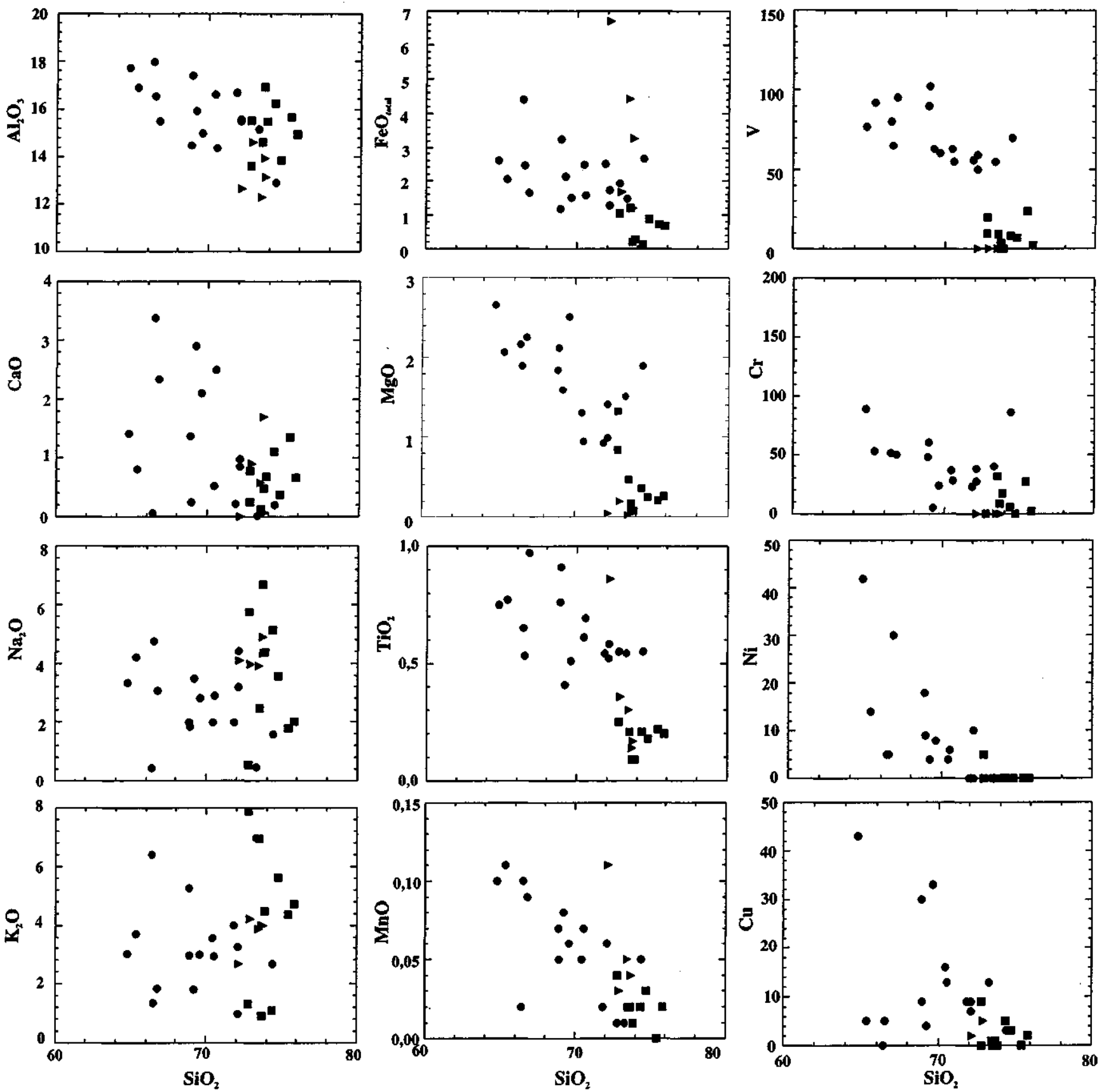

Gnaisse alcalino

Metagranitóide

Metavulcânica félsica

ïura S - Diagramas de Harker das rochas metavulcânicas félsicas, metagranitóides e gnaisses alcalinos (grupo I).

com extinção ondulante. O plagioclásio $\left(\mathrm{An}_{05} \cdot 15\right)$ ocorre como fenoclastos ou como grãos menores na matriz. As dimensões, formatos e feicões de deformação são similares aos do feldspato potássico, exceto pela presença de macias onduladas. A mica branca é mais abundante em amostras mais deformadas, onde define a foliação e circunda fenoclastos dos feldspatos. $\mathrm{O}$ mineral em geral contém inclusões de opacos e bordas com biotita e clorita. A clorita resulta de transformação da biotita e dos feldspatos. A apatita ocorre como diminutas acículas inclusas em feldspatos e como cristais maiores na matriz, onde pode alcançar até $0,10 \mathrm{~mm}$, sugerindo tratar-se de um mineral primário. Os opacos, em geral magnetita, ocorrem na matriz, comumente acompanhando a biotita, eventualmente como inclusões na mica branca. $\mathrm{O}$ epidoto é raro e, quando presente, está intercrescido com a biotita. $\mathrm{O}$ carbonato foi observado apenas em uma amostra, onde é intersticial à matriz.

Gnaisses alcalinos $\mathrm{O}$ primeiro registro da ocorrência de gnaisses alcalinos na Antiforme Capané é devido a Hartmann \& Jost (1980). Segundo os autores, os gnaisses afloram apenas no flanco oeste da estrutura, como um corpo tabular com $16 \mathrm{~km}$ de comprimento e 200 $\mathrm{m}$ de largura, concordante com as supracrustais. Esses gnaisses se caraterizam pela cor cinza avermelhada a vermelha e por um bandamento composicional dado pela alternância de níveis milimétricos ora ricos em feldspato potássico ora em piroxênio, anfibólio e opacos. A textura predominante é porfiroclástica média a fina, variável com a intensidade de deformação. A matriz é granoblástica fina, resultante de cominuição de porfiroclastos, e a estrutura é orientada. Os fenoclastos são de feldspato potássico e de minerais máficos, todos em geral prismáticos, de até $5,0 \mathrm{~mm}$ de comprimento (Fig. 4d), e com sombras de pressão e caudas de destruição. A presença de fenoclastos de anfibólio e de restos de piroxênio é a mais importante característica desses gnaisses.

Os minerais essenciais dos gnaisses compreendem quartzo (35$45 \%$ ), feldspato potássico (30-40\%), anfibólio (5-10\%), piroxênio $(3-5 \%)$ e magnetita (3-5\%). Alguns exemplares apresentam biotita (3-5\%), subordinadamente clorita, albita, mica branca, apatita, epidoto, turmalina e carbonato. 
Tabela l-Resultados de análises químicas das rochas metavulcânicas félsicas, intermediárias e máficas da Antíforme Capané. Óxidos maiores recalculados em base anidra (óxidos em \% em peso, elementos traços em ppm, n.a. $=$ não analisado, n.d. $=$ não detectado).

\begin{tabular}{|c|c|c|c|c|c|c|}
\hline & \begin{tabular}{|l|} 
MAC- \\
01 \\
Félsica \\
\end{tabular} & \begin{tabular}{|l|} 
MAC-1399 \\
Félsica \\
\end{tabular} & $\begin{array}{l}\text { MAAC-135 C } \\
\text { Fólsica }\end{array}$ & \begin{tabular}{|l|} 
MAC-22 B \\
Intermediária
\end{tabular} & \begin{tabular}{|l|} 
MAC-271 \\
Intermediária
\end{tabular} & $\begin{array}{l}\text { MAC- } \\
40 \\
\text { Máfica }\end{array}$ \\
\hline $\begin{array}{l}\mathrm{SiO}_{2} \\
\mathrm{THO}_{2}\end{array}$ & $\begin{array}{r}72,12 \\
0,58\end{array}$ & $\begin{array}{r}68,89 \\
0,76\end{array}$ & $\begin{array}{r}65,35 \\
0,77\end{array}$ & $\begin{array}{r}62,08 \\
0,71\end{array}$ & $\begin{array}{l}56,3 \\
1,32\end{array}$ & $\begin{array}{r}51,74 \\
1,58\end{array}$ \\
\hline $\mathrm{Al}_{2} \mathrm{O}_{3}$ & 15,49 & 14,48 & 16,88 & 17,64 & 17,4 & 17,55 \\
\hline $\mathrm{Fe}_{2} \mathrm{O}_{3}$ & 1,29 & 1,18 & 2,05 & 2,78 & 2,84 & 3.09 \\
\hline $\mathrm{FBO}$ & 2,06 & 4,02 & 3,92 & 4,12 & 5,96 & 7,22 \\
\hline $\mathrm{MnO}$ & 0,06 & 0,07 & 0.11 & 0.14 & 0.15 & 0,17 \\
\hline $\mathrm{MgO}$ & 0,99 & 1,84 & 2,06 & 2,96 & 4,67 & 5.11 \\
\hline $\mathrm{CaO}$ & 0,65 & $t, 37$ & 0,8 & 3,77 & 6,59 & 7,53 \\
\hline $\mathrm{Na}_{2} \mathrm{O}$ & 3.19 & 1,99 & 4,19 & 4,48 & 3,56 & 3.49 \\
\hline $\mathrm{K}_{2} \mathrm{O}$ & 3,25 & 5,26 & 3.7 & 1.01 & 0,61 & 1,49 \\
\hline $\mathrm{P}_{2} \mathrm{O}_{5}$ & 0.13 & 0.14 & 0,17 & 0.31 & 0.61 & 1,02 \\
\hline Total & 100 & 100 & 100 & 100 & 100 & 100 \\
\hline $\mathrm{H}_{2} \mathrm{O}$ & 0,99 & 0,53 & 0,84 & 2,34 & 1,17 & 1,35 \\
\hline $\mathrm{Cr}$ & 27 & 48 & 53 & 69 & 43 & 62 \\
\hline $\mathrm{Ni}$ & n.d. & 18 & 14 & 30 & 42 & 49 \\
\hline Co & 114 & 91 & 107 & 103 & 136 & 114 \\
\hline $\mathrm{Sc}$ & 8,7 & 13,7 & n.a. & n.a. & 19,6 & 21 \\
\hline v & 59 & 90 & 92 & 110 & 165 & 115 \\
\hline $\mathrm{Cu}$ & 7 & 30 & 5 & 6 & 50 & 36 \\
\hline $\mathrm{Zn}$ & 56 & 53 & 75 & 65 & 55 & 96 \\
\hline$R b$ & 203 & 194 & n.a. & n.a. & 20 & 35 \\
\hline Cs & 16 & 9.4 & n.a. & n.a. & n.d. & n.d. \\
\hline $\mathrm{Ba}$ & 700 & 1250 & 605 & 790 & 520 & 2360 \\
\hline $\mathrm{Sr}$ & 150 & 160 & 150 & 630 & 700 & 1300 \\
\hline $\mathbf{T a}$ & 2,6 & 2,6 & n.a. & n.a. & 1,1 & 1 \\
\hline $\mathrm{Nb}$ & 4 & 2 & 5 & 2 & 2 & 3 \\
\hline $\mathrm{Hf}$ & 10,1 & 6,1 & n.a. & n.a. & 3,6 & 3,78 \\
\hline $\mathrm{Zr}$ & 160 & 94 & 240 & 50 & 63 & 28 \\
\hline$Y$ & 39 & 29 & 45 & 18 & 18 & 23 \\
\hline Th & 31.9 & 11,4 & n. $\mathbf{a}$ & n.a. & 1,32 & 1,35 \\
\hline$u$ & 6.5 & 2,2 & n.a. & n.a. & n.d. & n.d. \\
\hline La & 52 & 33 & 41 & 27 & 33 & 85 \\
\hline$C_{\theta}$ & 88 & 75 & 98 & 57 & 72 & 175 \\
\hline $\mathrm{Pr}$ & n.a. & n.a. & n,a. & n.a. & n.a. & n.a. \\
\hline Nd & 44.3 & 33.3 & 41,6 & 19.7 & 39,3 & 71 \\
\hline $\mathrm{Sm}$ & 8.7 & 6.1 & 5,11 & 2,7 & 6,6 & 13,6 \\
\hline Eu & 1,3 & 1,05 & 0,89 & 0,66 & 2,52 & 3,8 \\
\hline Gd & n.a. & n.a. & 4,98 & 1,67 & n.a. & n.a. \\
\hline Tb & 1 & 0,9 & n.a. & n.a. & 0,6 & 1,1 \\
\hline Dy & n.a. & n.a. & 4,27 & 0,81 & n.a. & n.a. \\
\hline Ho & n.a. & n.a. & 0,81 & 0,14 & n.a. & ก.a. \\
\hline Er & n.a. & n.a. & 1,94 & 0,27 & n.a. & n.a. \\
\hline $\begin{array}{l}T m \\
Y_{b}\end{array}$ & $\begin{array}{r}\text { n.a. } \\
4.2\end{array}$ & $\begin{array}{r}\text { n.a. } \\
2,8\end{array}$ & n.a. & $\begin{array}{r}\text { n.a. } \\
0.17\end{array}$ & $\begin{array}{l}\text { n.a. } \\
1.56\end{array}$ & $\begin{array}{r}\text { n.a. } \\
1,66\end{array}$ \\
\hline
\end{tabular}

Tabela 2 - Resultados de análises químicas de amostras de metagranitóide e gnaisses alcalinos da Antiforme Capané. Óxidos maiores recalculados em base (óxidos em \% em peso, elementos traços em ppm, n.a. $=$ não analisado, $n . d .=$ não detectado).

\begin{tabular}{|c|c|c|c|c|c|}
\hline & \begin{tabular}{|l|} 
MAC-03 A \\
Metagranitoide
\end{tabular} & $\begin{array}{l}\text { MAC-39 A } \\
\text { Metagranitoide }\end{array}$ & $\begin{array}{l}\text { MAC-12日 } \\
\text { Metapranildide }\end{array}$ & $\begin{array}{l}\text { MAC-41 } \\
\text { Gnaisse Alcalino }\end{array}$ & $\begin{array}{l}\text { MAC-223 B } \\
\text { Gnaisse Alcalino }\end{array}$ \\
\hline $\mathrm{SiO}_{2}$ & 72,78 & 73.53 & 73,85 & 73,46 & 72,2 \\
\hline $\mathrm{TO}_{2}$ & 0,55 & 0,21 & 0,09 & 0.3 & 0,86 \\
\hline $\mathrm{A}_{2} \mathrm{O}_{3}$ & 13,64 & 14,62 & 15.48 & 12,3 & 12,66 \\
\hline $\mathrm{Fe}_{2} \mathrm{O}_{2}$ & 1,93 & 1,22 & 0,28 & 4,42 & 6.7 \\
\hline FeO & 1.05 & 0,33 & 0,65 & 1,05 & 0,66 \\
\hline MnO & 0,01 & 0,02 & 0,01 & 0,05 & 0,11 \\
\hline $\mathrm{MgO}$ & 1,32 & 0,46 & 0,08 & 0,02 & 0,04 \\
\hline $\mathrm{CaO}$ & 0,25 & 0,13 & 0,68 & 0,58 & 0,01 \\
\hline $\mathrm{Na}_{2} \mathrm{O}$ & 0,54 & 2,47 & 4,37 & 3,9 & 4,06 \\
\hline$K_{2} \mathrm{O}$ & 7,88 & 6,94 & 4,48 & 3,08 & 2,68 \\
\hline $\mathrm{P}_{2} \mathrm{O}_{6}$ & 0,06 & 0,06 & 0,02 & 0,02 & 0,03 \\
\hline Total & 100 & 100 & 100 & 100 & 100 \\
\hline $\mathrm{H}_{2} \mathrm{O}$ & 1,16 & 0.7 & 0.52 & 0,68 & 1,03 \\
\hline $\mathrm{Cr}$ & n.d. & 32 & 17 & n.d. & n.d. \\
\hline$C_{0}$ & 64 & 113 & 116 & 83 & 93 \\
\hline v & 10 & 9 & n.d. & n.d. & n.d. \\
\hline $\mathrm{Cu}$ & n.d. & n.d. & n.d. & 1 & 2 \\
\hline $2 n$ & 41 & 28 & 18 & 98 & 116 \\
\hline Ba & 1150 & 1600 & 170 & 37 & 100 \\
\hline sr & 61 & 232 & 6 & n.d. & n.t. \\
\hline $\mathrm{Zr}$ & 287 & 91 & 120 & 335 & 590 \\
\hline$\pi$ & 3297 & t259 & 540 & 1799 & 5156 \\
\hline$Y$ & 23 & 10 & 87 & 32 & 66 \\
\hline $\mathrm{Be}$ & 2 & 1 & 2 & 5 & 4 \\
\hline
\end{tabular}
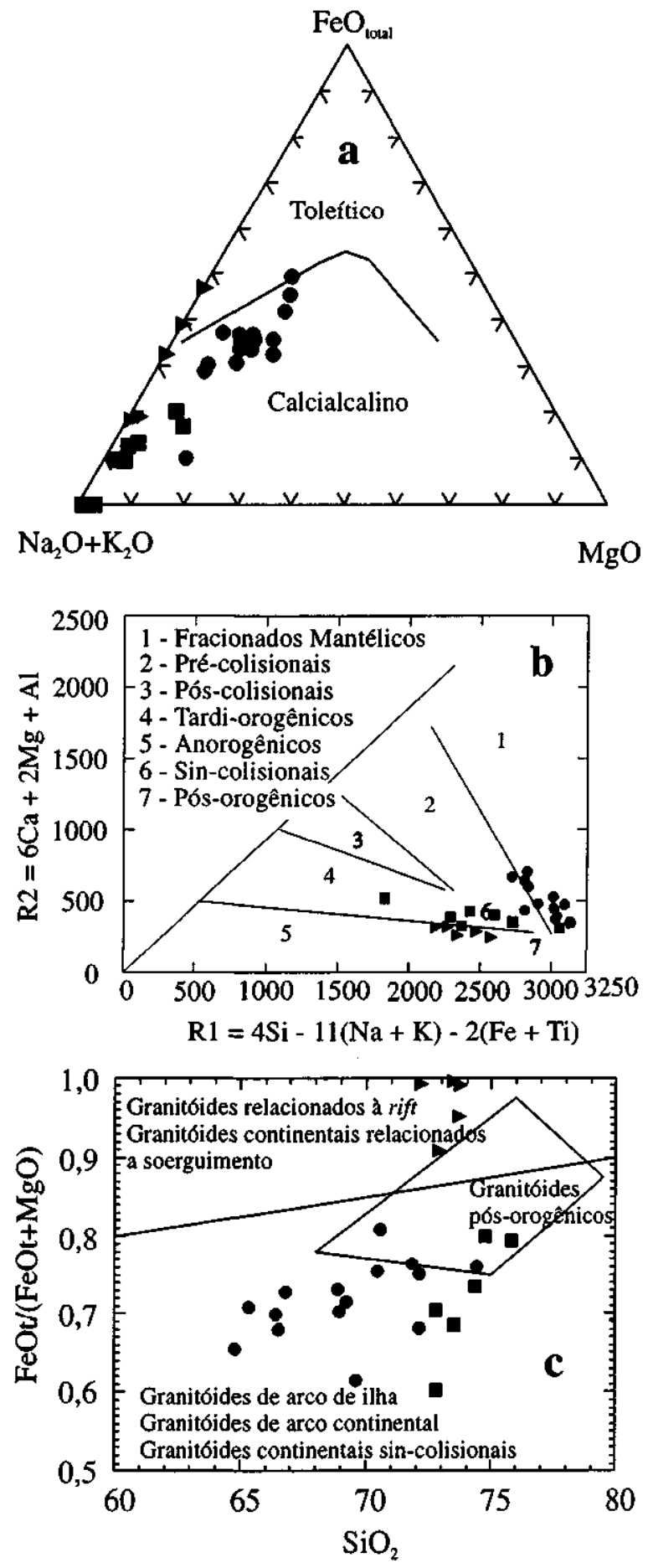

Gnaisse alcalino Metagranitóide

Metavulcânica félsica

Figura 6 - Diagramas petrológicos para rochas metavulcânicas félsicas, metagranitóides e gnaisses alcalinos (grupo 1). (a) AFM (Irvine e Baragar 1971); (b) diagrama multicationico RI x R2 (Batchelor e Bowden 1985); (c) diagrama $\mathrm{SiO}_{2} \times \mathrm{FeO} /(\mathrm{FeO}+\mathrm{MgO}$ ) (Maniar e Piccoli 1989).

O quartzo ocorre apenas na matriz, tem extinção ondulante e, com deformação pronunciada está estirado ou forma ribbons. Por vezes constitui parte das sombras de pressão de porfiroclastos.

O feldspato potássico ocorre como fenoclastos e como constituinte da matriz. Os fenoclastos apresentam macias carlsbad, em grade, típica de microclínio, em chama, e exsoluções de quartzo e albita. Feições comuns resultantes de deformação consistem de subgrãos, caudas de 

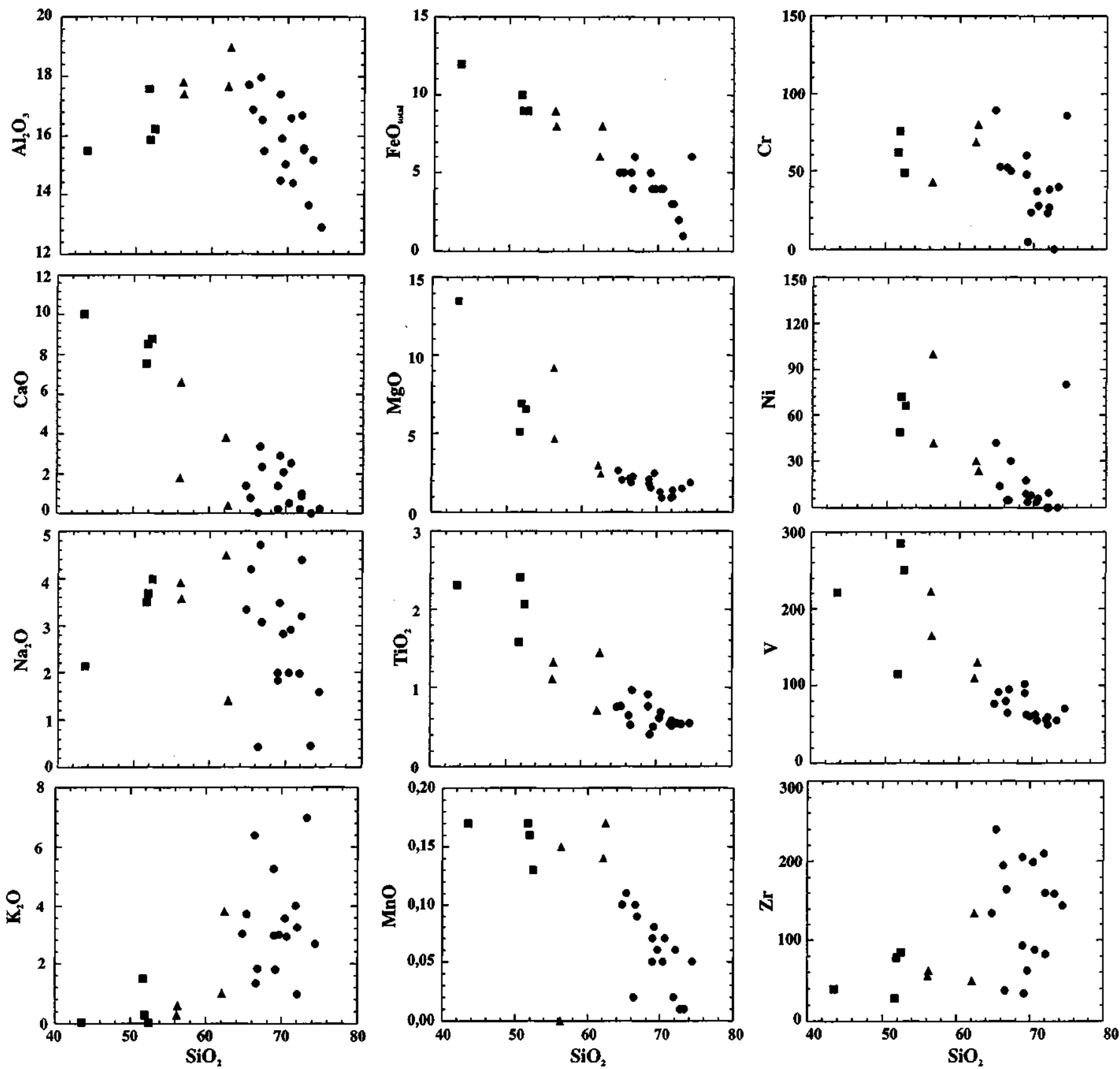

Metavulcânica félsica A Metavulcânica intermediária Metavulcânica máfica

Figura 7 - Diagramas de Harker das rochas metavulcânicas félsicas, intermediárias e máficas (grupo 2).

destruição e sombras de pressão. O feldspato da matriz é muito fino e está parcialmente transformado em mica branca e resulta da destruição de fenoclastos.

O piroxênio só ocorre em fenoclastos, comumente maclados. Com deformação crescente, o piroxênio adquire extinção ondulante, sombras de pressão e se transforma progressivamente em anfibólio até completo desaparecimento. $\mathrm{O}$ anfibólio está associado ao piroxênio nas rochas menos deformadas e à clorita e biotita nas mais deformadas. Dados composicionais obtidos por Hartmann \& Jost (1980) por meio de microssonda eletrônica mostram que o piroxênio é uma aegirinaaugita e o anfibólio é uma riebeckita. Nos termos menos deformados, ambos minerais são sempre intersticiais aos feldspatos, como esperado em rochas alcalinas de tendência geoquímica agpaítica.

A magnetita está sempre intercrescida com piroxênio e anfibólio. A albita resulta de exsoluções do feldspato potássico ou ocorre disseminada na matriz, onde apresenta macias e as mesmas feições de deformação que o feldspato potássico. A mica branca é produto de alteração dos feldspatos, a apatita ocorre como diminutas acículas em feldspatos ou como cristais de até $0,05 \mathrm{~mm}$ na matriz, e a biotita e clorita estão intercrescidas e resultam de transformação do anfibólio. Epidoto, turmalina e carbonato somente ocorrem nos exemplares mais deformados, particularmente quando nas proximidades dos metagranitóides, sugerindo associação com estes.

GEOQUÍMICA Métodos analíticos De um total de 94 amostras estudadas em lâminas delgadas e 10 em seções polidas de rochas metavulcânicas e metaplutônicas selecionou-se as menos deformadas para análise química. Os óxidos de elementos maiores e menores foram determinados no Laboratório de Geoquímica do Centro de Estudos em Petrologia e Geoquímica do Instituto de Geociências da Universidade Federal de Rio Grande do Sul, por meio de Fluorescência de Raios-X, em equipamento RIGAKU, modelo SIX-2000, empregando pastilhas de pó fundidas com Tetraborato de Lítio $(5 \mathrm{~g})$ e lodeto 

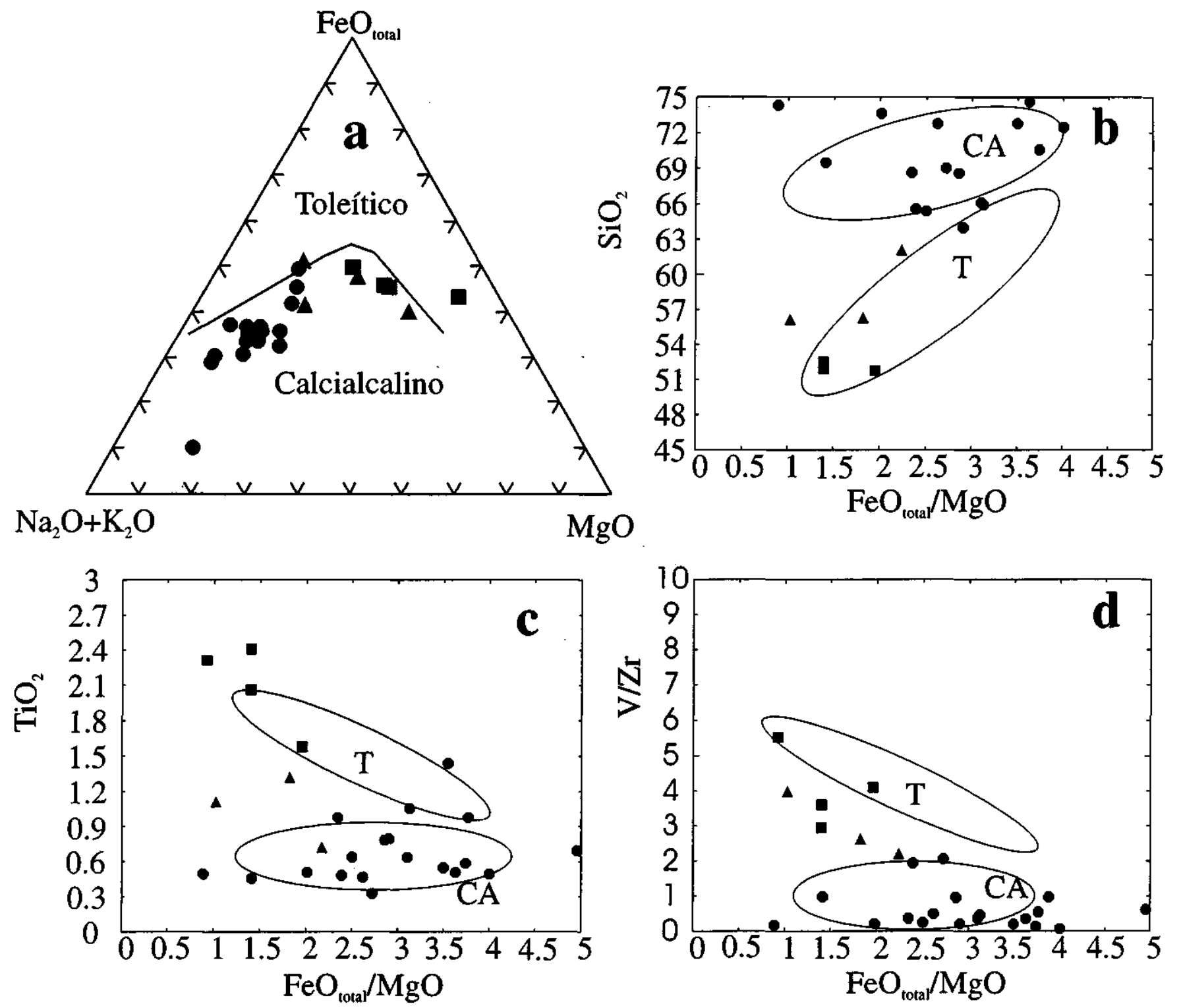

- Metavulcânica félsica $\Delta$ Metavulcânica intermediária Metavulcânica máfica

Figura 8 - Diagramas petrológicos das rochas metavulcânicas félsicas, intermediárias e máficas (grupo 2). (a) AFM (Irvine e Baragar 1971); (b) $\mathrm{SiO}_{2} \times \mathrm{FeO}_{\text {total }} \mathrm{MgO}$; (c) $\mathrm{TiO}_{2} \times \mathrm{FeO}_{\mathrm{tota}} / \mathrm{MgO}$; (d) $\mathrm{V} / \mathrm{Zr} \times \mathrm{FeO}$ total $/ \mathrm{MgO}$. Os campos CA (calcialcalino) e $\mathrm{T}$ (toleiticos) dos diagramas $9 b$, $9 c$ e $9 d$ foram extraídos de Tamura (1994).

de Lítio a $1 \%(0,25 \mathrm{ml})$. O $\mathrm{Na}_{2} \mathrm{O}$ foi analisado por Fotometria de Chama, $0 \mathrm{FeO}$ pelo Método de Wilson (1955) e o $\mathrm{Fe}_{2} \mathrm{O}_{3}$ recalculado por estequiometria. Os elementos traços $\mathrm{Cr}, \mathrm{Ni}, \mathrm{Co}, \mathrm{V}, \mathrm{Cu}, \mathrm{Zn}, \mathrm{Ba}, \mathrm{Sr}, \mathrm{Zr}$ e Y foram analisados por ICP no Laboratório de Geoquímica do Instituto de Geociências da Universidade de Brasília, por decomposição ácida da amostra com $\mathrm{HF} / \mathrm{HClO}_{4} / \mathrm{HNO}_{3}$ e $\mathrm{HCI}$, e fusão dos resíduos com $\mathrm{LiBO}_{2}$ (Boaventura 1991) e determinação em um espectrômetro SPECTRO FVMO3, com distância focal de $75 \mathrm{~cm}$, montagem Paschen-Runge. A reprodutibilidade de resultados analíticos foi controlada mediante réplica de uma amostra a cada grupo de dez amostras analisadas e algumas análises de $\mathrm{FeO}_{\text {total }}$ foram refeitas por Volumetria Redox. Os padrões analíticos foram preparados nas mesmas condições e no mesmo dia. Leituras dos padrões foram efetuadas a cada cinco amostras analisadas. Quatro amostras foram analisadas para $\mathrm{Sc}, \mathrm{Rb}$, Cs, Ta, Hf, Th e ETR por ativação neutrônica no Instituto de Pesquisas Energéticas e Nucleares (IPEN), São Paulo, e duas para ETR por Fluorescência de Raios-X na GEOSOL - Geologia e Sondagens Ltda., Belo Horizonte. Alguns exemplos de resultados analíticos constam das Tabelas 1 e 2.

Resultados $\mathrm{O}$ tratamento dos dados mostrou-se mais adequado reunindo as rochas analisadas em dois grupos distintos. O Grupo
1 engloba as metavulcânicas félsicas, metagranitóides e gnaisses alcalinos e permite investigar diferenças, semelhanças e possíveis vínculos genéticos entre os trềs tipos de rochas. $\mathrm{O}$ Grupo 2 reúne as rochas metavulcânicas félsicas, intermediárias e máficas e permite avaliar as relações composicionais entre estas.

A limitada quantidade de dados analíticos dificulta, de momento, qualquer tentativa de modelamento magmático, mas permite estimar os prováveis ambientes tectônicos aos quais os respectivos protólitos se associam.

GRUP0 1 Os diagramas da figura 5 mostram que, apesar da variação de $\mathrm{Al}_{2} \mathrm{O}_{3}, \mathrm{MgO}, \mathrm{TiO}_{2}$ e $\mathrm{MnO}$ com $\mathrm{SiO}_{2}$ sugerirem que os metagranitóides, os gnaisses alcalinos e as metavulcânicas félsicas constituem um único trend magmático, este não se cumpre com os demais óxidos e elementos traços. Claramente as metavulcânicas félsicas se distinguem das demais na variação do $\mathrm{CaO}, \mathrm{Na}_{2} \mathrm{O}$ e $\mathrm{K}_{2} \mathrm{O}$, relacionados com 0 fracionamento de feldspatos e os gnaisses alcalinos se distinguem das vulcânicas e do metagranitóide pelo trend independente do $\mathrm{FeO}_{\text {total }}$. Quantitativamente, os metagranitóides e os gnaisses alcalinos, comparativamente às metavulcânicas, são mais ricos em $\mathrm{SiO}_{2}$ e mais pobres em $\mathrm{MgO} . \mathrm{O} \mathrm{Al}_{2} \mathrm{O}_{3}$ é mais abundante nas rochas metavulcânicas félsicas e metagranitóides e mais baixo nos gnaisses alcalinos. Apesar da 

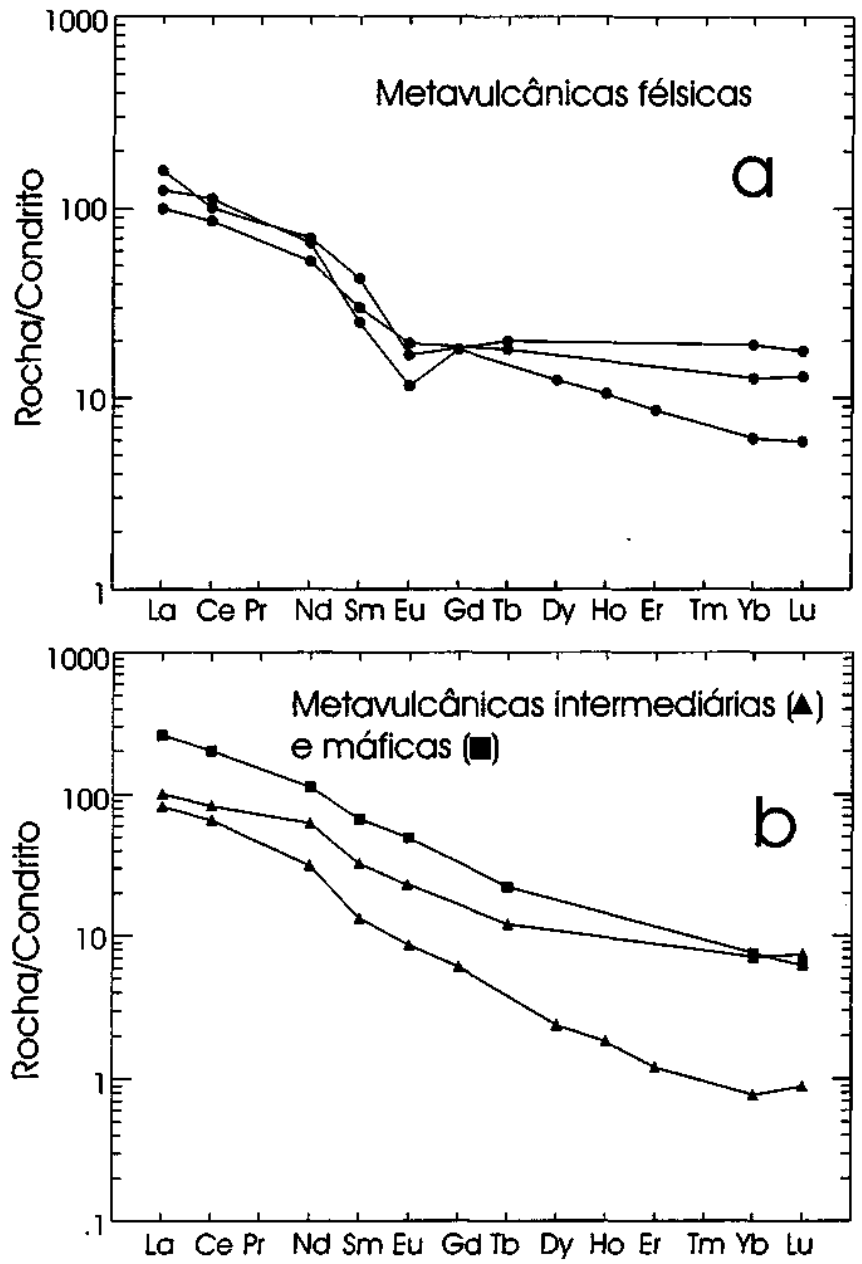

Figura 9 - Comportamento dos ETR das rochas do grupo 2, (a) rochas metavulcânicas félsicas e (b) rochas metavulcânicas intermediárias a máficas.

dispersão do $\mathrm{CaO}, \mathrm{Na}_{2} \mathrm{O}$ e $\mathrm{K}_{2} \mathrm{O}$ nos três litotipos, o que deve refletir sua mobilização durante o metamorfismo, em geral as metavulcânicas são mais ricas em $\mathrm{CaO}$ que os metagranitóides e os gnaisses alcalinos. Apesar da variação de $\mathrm{Na}_{2} \mathrm{O}$ e $\mathrm{K}_{2} \mathrm{O}$ das metavulcânicas desenhar um trend independente dos metagranitóides e gnaisses alcalinos, quantitativamente não há diferenças substanciais entre os três litotipos.

Em geral, os metagranitóides são mais evoluídos e se diferenciam dos gnaisses alcalinos pêlos teores menores de $\mathrm{FeO}_{\text {total }} \mathrm{TiO}_{2}$ e $\mathrm{MnO}$ e maiores de $\mathrm{MgO}$.

No diagrama da figura $6 \mathrm{a}$, as amostras de metagranitóide se dispõem segundo um trend aproximado cálcio-alcalino, o que é compatível com o seu caráter sin-cinemático interpretado a partir dos dados de campo e texturais. Já as amostras de rochas metavulcânicas félsicas se dispõ em segundo um trend diagonal, mais próximo dos produtos mais diferenciados de um trend toleiítico e as de gnaisses alcalinos apenas se distribuem ao longo da aresta entre $\mathrm{FeO}_{\text {total }}$ e $\mathrm{Na}_{2} \mathrm{O}+\mathrm{K}_{2} \mathrm{O}$, sem definição de um trend específico.

No diagrama multicatiônico RlxR2 da figura $6 \mathrm{~b}$, as amostras de metagranitóide mostram uma boa correlação com ambientes sin-colisionais a tardi-orogênicos, com os gnaisses alcalinos superpondo-se no mesmo campo. Contudo, as metavulcânicas félsicas distribuem-se preferencialmente no campo dos fracionados mantélicos.

$\mathrm{Na}$ figura $6 \mathrm{c}$, os gnaisses alcalinos nitidamente se distinguem dos demais litotipos pela distribuição das amostras no campo de granitóides relacionados a rifts ou continentais vinculados a soerguimento. Já as amostras de granitóides da área se distribuem preferencialmente no campo dos sin-colisionais, com tendência a pósorogênicos, compatível com a sua disposição nos diagramas das figuras $6 \mathrm{a}$ e $6 \mathrm{~b}$. As metavulcânicas félsicas também se distribuem entre esses dois campos, mas segundo um trend de variação da razão $\mathrm{FeO}_{\text {total }} /\left(\mathrm{FeO}_{\text {total }}+\mathrm{MgO}\right)$ distinta daquela das amostras de metagranitóide, mas incompatível com os trends obtidos nas figuras $6 \mathrm{a}$ e $6 \mathrm{~b}$, o que permite descartar a figura $6 \mathrm{c}$ como diagnostica de ambiente tectônico para estas rochas.

Do exposto se conclui que os metagranitóides, gnaisses alcalinos e rochas metavulcânicas félsicas da Antiforme Capané possuem propriedades geoquímicas distintas. A associação dos metagranitóides com estreitas e longas zonas de cisalhamento e seus efeitos de contato, ainda que sutis, sobre as supracrustais, nas quais a intrusão ocorreu após o pico metamórfico, combinado com os dados geoquímicos permite interpretá-los como sin-colisionais. Os gnaisses alcalinos, por outro lado, foram submetidos aos mesmos eventos deformacionais e metamórficos que as supracrustais, e, de modo idêntico aos metagranitóides, com sutis efeitos de contato sobre estas. A natureza geoquímica desses gnaisses, como revelada pela figura $6 \mathrm{c}$, permite interpretá-los como uma intrusão alcalina. Os dados petrográficos e texturais revelam que o piroxênio sódico, assim como o anfibólio sódico dele derivado, são nitidamente tardios em relação ao feldspato potássico, típico de rochas alcalinas com tendência geoquímica agpaítica. Em vista disso, interpretamos esses gnaisses como equivalentes metamórficos de uma intrusão alcalina da fase de extensão crustal do estágio de bacia da Suíte Metamórfica Porongos, como nova alternativa à interpretação sedimentar dada por Hartmann \& Jost (1980) para esses gnaisses, e de acordo com a interpretação ígnea dada por Camozzato et al.(1994) para ocorrências similares da região de Candiota, no extremo sul da faixa de ocorrência da Suíte.

Grupo 2 Alguns dos diagramas de Harker (Fig. 7) mostram trends distintos entre as rochas metavulcânicas máficas a intermediárias e as félsicas. Nas rochas félsicas há diminuição de $\mathrm{Al}_{2} \mathrm{O}_{3}, \mathrm{Na}_{2} \mathrm{O}, \mathrm{MnO}$ e $\mathrm{Cr}$ com a diferenciação, como esperado, ao passo que nas intermediárias a máficas as proporções destes elementos crescem com a diferenciação, o que pode refletir evolução distinta ou apenas fracionamento mineralógico. A variação do $\mathrm{Al}_{2} \mathrm{O}_{3}$ com $\mathrm{SiO}_{2}$ pode ser explicada pelo fracionamento preferencial de piroxênio cálcico nos termos mais primitivos e por feldspatos nos mais evoluídos, o que é compatível com a variação dos demais óxidos de elementos maiores. O fracionamento segundo um único trend podeia ser deduzido a partir da variação de $\mathrm{Ni}$, V e Zr, apesar da dispersão deste último, a qual que pode resultar de imprecisão.

No diagrama AFM (Fig. 8a), o conjunto de rochas metavulcânicas descreve uma curva similar ao do limite entre os campos toleiítico e cálcio-alcalino, sugerindo que estas podem ser cogenéticas. Contudo, nos demais diagramas (Figs. 8b, c e d), as metavulcânicas félsicas se agrupam preferencialmente no campo cálcio-alcalino e as máficas e intermediarias no dos toleiítos.

Os dados de ETR normalizados ao condrito (Fig. 9) mostram que as rochas félsicas apresentam um enriquecimento em ETRL e um padrão plano dos ETRP, com uma razão $\mathrm{La}_{\mathrm{N}} / \mathrm{Yb}_{\mathrm{N}}$ variável de 9 a 20 , e uma forte anomalia negativa de Eu. A anomalia negativa de Eu indica fracionamento de plagioclásio (McKay 1989), e o enriquecimento relativo de ETRP que pode sugerir uma fusão a partir de granada peridotitos (McDonough \& Frey 1989) ou um enriquecimento metamórfico (Grauch 1989). Já as rochas máficas a intermediárias mostram forte enriquecimento em ETRL, com razão $\mathrm{La}_{\mathrm{N}} / \mathrm{Yb}_{\mathrm{N}}$ entre 20 e 100, e fracionamento linear dos ETRP, sem anomalia negativa de Eu (Fig. 9b).

Comparando os dados da Antiforme Capané com os do Grupo Shirahama do Japão, que consiste de um magmatismo Mio-Pliocênico bimodal toleiítico/cálcio-alcalino de arco (Tamura 1994), nota-se uma boa correlação das rochas félsicas com o tipo cálcio-alcalino e das rochas intermediárias a máficas com o tipo transicional para o toleiítico (Fig. 8b, c, d, e). No entanto, o padrão de ETR é transicional para o de rochas alcalinas, com razões de $\mathrm{La}_{\mathrm{N}} / \mathrm{Yb}_{\mathrm{N}}$ entre 20 e 100 e ZETR entre 170 e 340 . Roden et al. (1984) sugerem que enriquecimento de ETR pode estar relacionado a um metassomatismo que resultou na infiltração de fluidos derivados da devolatização da placa em muitas zonas de subducção. Estes fluidos podem transferir, da placa para o manto através de fases hidratadas, elementos como LILE e ETRL, posteriormente incorporados à crosta continental (Saunders et al. 1991). Neste sentido, destaca-se que as rochas máficas e intermediárias são mais abundantes em LILE do que em HFSE, o que, segundo Bednarz \& Schmincke (1994) pode ser considerado um critério para distinguir magmas gerados em ambientes de subducção, visto que elementos como os HFSE são insolúveis em fluidos hidratados e tendem a permanecer na placa em subducção e porções mantélicas adjacentes (Saunders et al 1991).

Duas associações podem ocorrer em zonas de subducção, uma com baixa e outra com alta razão $\mathrm{Ce} / \mathrm{Yb}$, com enriquecimento seletivo de 
elementos traço (Hawkesworth et al. 1991). O segundo tipo reflete uma contribuição de crosta preexistente ou fonte mantélica enriquecida, o que representaria uma evolução em áreas tectônicas complexas (Hawkesworth et al. 1991). Isto é compatível com a região leste dos terrenos pré-cambrianos do Rio Grande do Sul, onde a preexistência de um continente mais antigo é evidente (Frantz \& Botelho 1997), e pode explicar o padrão litoquímico das rochas metavulcânicas intermediárias a máficas da Antiforme Capané. O ambiente gerador destas rochas poderia, portanto, estar relacionado a zonas de subducção, o que parece razoável uma vez que as lentes de rochas metaultramáficas desta mesma área indicam uma afinidade mantélica, possivelmente parte de um ofiólito desmembrado (Marques et al. 1996).

O caráter variado da natureza geoquímica das rochas metavulcânicas félsicas (cálcio-alcalinas) e máficas a intermediárias (transicional a toleiíticas) pode ser explicado também pela associação com ambientes de subducção. Tamura (1994) mostra que, em zonas de subducção, diápiros peridotíticos hidratados são aquecidos e parcialmente desidratados durante a ascensão. $\mathrm{O}$ interior do diápiro aquecido pode preservar zonas frias e hidratadas que podem originar magma boninítico. As porções externas, quentes e secas, tendem a produzir magma basáltico. Ambos magmas podem evoluir, respectivamente, para uma série toleiítica e cálcio-alcalina nos níveis mais altos da câmara magmática, com ou sem misturas, o que justificaria a natureza híbrida das rochas metavulcânicas máficas a intermediárias da área estudada. Isto explicaria, também, a íntima relação destas rochas com metavulcânicas félsicas e suas diferenças geoquímicas, sem necessidade de invocar ambientes tectônicos diversos.

CONSIDERAÇÕES FINAIS A Suíte Metamórfica Porongos na região da Antiforme Capané consiste de uma sequência de rochas metassedimentares e metavulcânicas máficas até félsicas, com intercalações de rochas metaultramáficas, gnaisses alcalinos e intrusões tabulares concordantes de metagranitóides.

As rochas metavulcânicas máficas a intermediárias não preservam estruturas e texturas primárias diagnosticas do estilo das erupções. Já as metavulcânicas félsicas são tufáceas, indicando um regime explosivo. As intercalações de metachert sugerem que, ao menos em parte, $\mathrm{o}$ vulcanismo foi sub-aquoso. A associação das rochas metavulcânicas com as metassedimentares mostra que o vulcanismo foi, durante certo período de tempo, concomitante com a sedimentação. O estado de deformação e transposição da Suíte Metamórfica Porongos dificultam estabelecer o intervalo durante o qual o vulcanismo foi mais efetivo que a sedimentação.

A natureza geoquímica das rochas metavulcânicas félsicas é compatível com a série cálcio-alcalina, enquanto a das metavulcânicas máficas a intermediárias é transicional entre as séries toleiítica e cálcio-alcalina. É importante ressaltar que o conteúdo de ETR destas sequências é elevado, especialmente os ETRL. Segundo Fallon \& Green (1990), Saunders et al. (1991), Hawkesworth et al. (1991) e
Tamura (1994), estas características podem sugerir um vulcanismo associado à subducção, onde uma crosta preexistente favorece o enriquecimento em LILE e ETRL. Outros dados (Marques et al. 1996 Frantz \& Botelho 1997) corroboram com esta interpretação. Daí conclui-se que o vulcanismo da Suíte Metamórfica Porongos na Antiforme Capané é produto de magmatismo associado à subducção de crosta oceânica sob uma crosta continental, provavelmente representada pelos Gnaisses Encantadas que afloram no núcleo do Domo de Santana da Boa Vista.

Os dados litoquímicos de rochas metavulcânicas da Suíte Metamórfica Porongos na região de Santana da Boa Vista, particularmente os altos teores de $\mathrm{K}_{2} \mathrm{O}$ de metandesitos, foram interpretados por Jost \& Bitencourt (1980) e Jost (1981) como sugestivos de ambiente de retroarco. Posteriormente, Porcher \& Fernandes (1990) e Fernandes et al. (1992) as reintepretaram como de back-arc. As características geoquímicas distintas das rochas metavulcânicas da Antiforme Capané implicam em que não é possível descartar um vulcanismo associado com um arco, o que, por sua vez, implicaria em uma variação paleogeográfica e paleotectônica ao longo da bacia original.

Por outro lado, a natureza petrográfica e geoquímica dos gnaisses alcalinos são típicas de rochas ígneas alcalinas agpaíticas $(\mathrm{Na}+\mathrm{K}>\mathrm{Al})$. A sua intercalação nas supracrustais, com evidências de deformação concomitante, sinaliza que o evento magmático alcalino pode ter ocorrido antes ou durante a sedimentação e denuncia um evento extensional do tipo rift, precursor da bacia sedimentar Porongos.

Assim, a sedimentação plataformal preconizada por Jost (1984) e Marques et al. (1998) e sua coexistência, de um lado, com rochas vulcânicas de afinidades variadas e, de outro, com rochas ígneas típicas de rift, mostram que a evolução paleogeográfica da bacia Porongos foi complexa e, na literatura até então produzida, ainda não resolvida tendo em vista a natureza compartimentada dos diversos trabalhos. Um entendimento melhor da bacia somente será alcançado quando houver uma integração dos diversos compartimentos. Mesmo assim, esta será dificultada pela extrema fragmentação da bacia e justaposição de ambientes distintos ao longo de um estreito segmento, apesar de longo. Por outro lado, as relações dos metagranitóides com as supracrustais são características de intrusões sin-cinemáticas. A sua natureza peraluminosa cálcio-alcalina sugere magmas tardios na evolução de um arco, o que é compatível com seu caráter sin-tectônico e com o ambiente sugerido para a formação das rochas vulcânicas.

Agradecimentos Ao Conselho Nacional de Desenvol-vimento Científico e Tecnológico - CNPq, Institutos de Geociências das Universidades Federal do Rio Grande do Sul e de Brasília pelos suportes financeiros para trabalhos de campo e de laboratório. À Dra. Ana Maria Graciano Figueiredo do Instituto de Pesquisas Energéticas e Nucleares pelas análises por ativação neutrônica no CNEN/IPEM, São Paulo. Ao bolsista de Iniciação Científica/PIBIC Ivan de Andrade de Oliveira pela participação em fases de mapeamento.

\section{Referências}

Batchelor, R.A. \& Bowden, P. 1985. Petrogenetie Interpretation of granitoid rock series using multicationic parameters. Chemical Geology, 48:43-55

Bednarz, U. \& Schmincke, H.U. 1994. Petrological and chemical evolution of the northeastern Troodos extrusive series, Cyprus. Journal of Petrology, 35:489-523

Boaventura, G.R. 1991. Performance do espectrômelro de emissão com plasma (ICP), speclroflame FVMO3, para determinação de 20 elementos químicos nas amostras de referência geoquímica DNC-1, W-2, UNB B-1 c UNB G-1. In: SBGq, Cong. Brás. Gcoq., 1, São Paulo, Anais, 1-.423-426

Camozzato, E.; Sander, A.; Ramgrab, G.E.; Wildncr, W. 1994. Milonitos alcalinos-peralcalinos da região de Candiota, RS. In: SBG, Cong. Brás. Geol., 38, Balneário Camboriú, Boletim de Resumos Expandidos, 3:89-90

Falloon, T.J. \& Green, D.H. 1990. Solidus of carbonated fertile peridotite under fluid-saturated conditions. Geology, 18:195-199

Fernandes, L.A.D.; Tommasi, A.; Porcher, C.C. 1992. Deformation patters in the southern brazilian branch of Dom Feliciano belt: a reappraisal. Journal of South American Earth Sciences, 5:77-96

Frantz, J.C. \& Botelho, N.F. 1997. Os Granitóides Estaníferos do Rio Grande do Sul, Zonas de Cisalhamento Transcorrente e Geração de Greisen Estruturalmente Controlados. In: SBG/ Núcleo Brasília/ IG-UnB, Simpósio Nacional de Estudos Tectônicos, 6, Pirenópolis, Anais, 313-315

Grauch, R.I. 1989. Rare earth clements in metamorphic rocks. In: B.R. Lipin \& G.A. McKay (eds) Reviews in Mineralogy, Mineralogical Society of America, 21:147-168

Hartmann, L.A. \& Jost, H. 1980. Gnaisses alcalinos da Antiforme Capané. Acta Geológica Leopoldensia, 4(7): 13-25

Hawkesworth, C.J.; Hergt, J.M.; Ellam, R.M.; McDermott, F. 1991. Element (luxes associated with subduction related magmatism. Phil Trans. R. Soe. Lona. A, 335(1638):393-405

Irvine, T.N. \& Baragar, W.A.R. 1971. A guide to the chemical classification of the common volcanic rocks. Canadian Journal of Earth Sciences. 8:523-548

Jost, H. 1981. Geology and metallogeny of lhe Santana da Boa Vista region southern Brasil. University of Georgia, Athens, PhD Thesis. 208p.

Jost, H. 1984. Sedimentação e vulcanismo durante o Ciclo Brasiliano no Rio Grande do Sul: uma revisão. SBG, Congresso Brasileiro de Geologia, 33, Anais.., pg.: 3241-3257
Jost, H. \& Bitencourt, M.F. 1980. Estratigrafia e tectônica de uma fração da faixa de dobramentos de Tijucas no Rio Grande do Sul. Acta geológica Leopoldensia, 7(6):27-60

Jost, H. \& Hartmann, L.A. 1979. Rodingitos do Rio Grande do sul, Brasil. Acta geológica Leopoldensia, 3(4):77-91

Maniar, P.D. \& Picoli, P.M. 1989. Tectonic discrimination of granitoids. Geological Society of America Bulletin, 101: 635-643

Marques, J.C. 1996. Petrologia e Metalogênese da Sequência Metaultramáfica da Antiforme Capané, Suite Metamórfica Porongos, Cachoeira do Sul-RS. Curso de Pós-Graduação em Geociências, Universidade Federal do Rio Grande do Sul, Porto Alegre, Dissertação de Mestrado, 196p

Marques, J.C.; Jost, H.; Roisenberg, A. 1998. Rochas metassedimentares, estrutural e metamorfismo da Suíte Metamórfica Porongos na área da Antiforme Capané, Cachoeira do Sul - RS. Revista Brasileira de Geociências, 28:519-526.

Marques, J.C.; Roisenberg, A.; Jost, H. 1996. Cromoespinélio como indicador petrogenético, Suíte Ultramáfica Cerro da Mineração (SUCM) - Antiforme Capané, Cachoeira do Sul-RS. In: SBG, Cong. Brás. Geol.,39, Salvador, Anais, 6:221-223

Marques.J.C. \& Caravaca.G. 1994. Eventos Tectono-Metamórficos do Complexo Cerro da Árvore, Suíte Metamórfica Porongos, Encruzilhada do Sul-RS. In: SBG, Congr. Brás. Geol., 38, Balneário Camboriú, Boletim de Resumos Expandidos, 2:73-74

McDonough, W.F. \& Frey, F.A. 1989. Rare earth clements in upper mantle rocks. In: B.R. Lipin \& G.A. McKay (eds) Reviews in Mineralogy, Mineralogical Society of America, 21:99-145

McKay, G.A. 1989. Partitioning of rare clements between major silicate minerais and basaltic melts In: B.R. Lipin \& G.A. McKay (eds) Reviews in Mineralogy, Mineralogical Society of America, 21:45-77

Middlemost, E.A.K. 1985. Magmas and Magmatic Rocks. Essex, Longman Group Limited.

Porcher, C.C. \& Fernandes, L.A.D. 1990. Relações embasamento/ "cobertura" na porção ocidental do cinturão Dom Feliciano: um esboço estrutural. Pesquisas, 17(1/2):72-96

Roden, M.F.; Frey, F.A.; Francis, D.M.1984. An example of consequent mantle metasomatism in peridotite inclusions from Nunivak Island, Alaska. Journal of Petrology, 25:546-577

Santos, E.L.; Ramgrab, G.E.; Maciel, L.A.; Mosmann, R. 1989. Mapa Geológico do estado do Rio Grande do Sul e parte do escudo Sul-rio-grandense. DNPM- $1^{0}$ Distrito Regional. 
Saunders, A.D.; Norry, M.J.; Tarney, J. 1991. Fluid influence on the trace element composilions of subduction zone magmas. Phil. Trons. R. Soe. Lond. A, 335( 1638):377-392

Soliani Júnior, E. 1986. Os Dados Geocronológicos do Escudo Sul-rio-grandense e suas Implicações de Ordem Geotectônica. Inst. de Geociências, Universidade de São Paulo, São Paulo, Tese de Doutoramento, 239p.

Tamura, Y. 1994. Génesis of island are magmas by mantle-deri ved bimodal magmatism: evidence from Shirahama group, Japan. Journal ofPetrology, 35(3):619-645

Teixeira, W. 1982. Folhas SH. 22 - Porto Alegre, SI. 22 -Lagoa Mirim e SH. 21 Uruguaiana. Interpretação dos dados radiométricos e evolução geocronoló gica. In: Projeto RADAMBRASIL, Florianópolis (relatório inédito)
Wildner, W.; Camozzato, E.; Orlandi Filho, V.; Basei, M.A.S. 1996. Rochas vulcanogênicas do Cinturão Metamórfico Porongos na Antiforme do Godinho, região do Passo da Cuia-RS. In: SBG, Cong. Brás. Geol., 39, Salvador, Anais, 2:146-148

Wilson, A.D. 1955. Determination of ferrous iron in rocks and minerais. Bull. Ceol. Surv.G. B., 9:56-58

Manuscrito A-965

Recebido em 18 de março de 1998

Revisã 0 dos autores em 30 de julho de 1998

Revisão aceita em 01 de agosto de 1998 